\title{
GAMBARAN AGRESIVITAS PADA REMAJA LAKI-LAKI SISWA SMA NEGERI DI DKI JAKARTA
}

\author{
Susi Fitri ${ }^{1}$ \\ Meithy Intan Rukia Luawo ${ }^{2}$ \\ Dewi Puspasari ${ }^{3}$
}

\begin{abstract}
Abstrak
Agresivitas remaja laki-laki adalah persoalan menyangkut perilaku baik fisik maupun lisan yang menyakiti, merusak baik secara fisik, psikis dan benda- benda yang ada di sekitarnya yang berkaitan dengan 4 aspek yakni aspek agresi fisik, agresi verbal, kemarahan, dan permusuhan yang dialami oleh remaja dengan rentang usia 15 - 18 tahun yang sedang menempuh pendidikan di Sekolah Menengah Atas (SMA). Tujuan penelitian ini untuk memperoleh gambaran mengenai agresivitas pada remaja laki-laki di SMA Negeri DKI Jakarta. Penelitian ini menggunakan metode survey dengan populasi penelitian diambil 20\% dari kecamatan di lima wilayah DKI Jakarta dengan teknik sampel adalah Gugus Bertahap Ganda (Multistages Random Sampling) dan sampel yang digunakan sebanyak 523 remaja laki-laki. Kuesioner yang digunakan pada penelitian ini merupakan instrumen adaptasi The Aggression Questionare yang terdiri dari 29 butir yang didapat dari 4 aspek yang merujuk pada teori yang dikembangkan oleh Buss\&Perry (1992). Skala yang digunakan pada penelitian ini ialah skala likert dengan pilihan jawaban dari sangat tidak sesuai sampai sangat sesuai. Dari hasil penelitian tersebut dapat disimpulkan bahwa remaja lakilaki memiliki tingkat agresivitas yang tinggi pada kategori sedang, aspek yang dominan dalam gambaran agresivitas remaja ini adalah aspek permusuhan dengan persentase $77.3 \%$.
\end{abstract}

Kata kunci: agresivitas, remaja laki-laki

\section{AGGRESSIVENESS ON TEENAGE BOYS IN PUBLIC HIGH SCHOOL STUDENTS IN DKI JAKARTA}

\begin{abstract}
Aggressiveness of teenage boys is a matter concerning the behavior of both physical and verbal hurt, damaging both physically, psychic and objects in the surrounding areas related to four aspects those are the aspects of physical aggression, verbal aggression, anger, and hostility that is experienced by teenager aged 15-18 years who are studying in public high school. The purpose of this research to obtain a snapshot of the aggressiveness on teenage boys high schools in DKI Jakarta. This study used survey method with the study population was taken $20 \%$ of districts in five areas of Jakarta with engineering samples are Phased Double Cluster (Multistages Random Sampling) and samples that used as many as 523 teenage boys. The questionnaire that is used in this study is an adaptation of The Aggression Questionare instrument consisting of 29 items were obtained from four aspects referring to the theory developed by Buss and Perry (1992). The scale used in this researchis the likert scale with a choice of answers from not very appropriate to suit. From these results it can be concluded that the boys have a

\footnotetext{
${ }^{1}$ Dosen Program Studi Bimbingan dan Konseling FIP UNJ, susi.fitri.kuliah@gmail.com

2 Dosen Program Studi Bimbingan dan Konseling FIP UNJ, meithy intan@yahoo.com

${ }^{3}$ Mahasiswa Program Studi Bimbingan dan Konseling FIP UNJ, dewi.puspasari.kuliah@gmail.com
} 
high level of aggressiveness in the medium category, the dominant aspect in this teenage description of aggressiveness is the aspect of hostility with a percentage of $77.3 \%$.

Keywords: agression, male teenager

\section{PENDAHULUAN}

Maskulin merupakan sebuah bentuk konstruksi kelelakian terhadap gender yang mencakup berbagai aspek karateristik individu seperti, karakter atau kepribadian, perilaku peranan, okupasi, penampilan fisik, ekspresi verbal maupun non verbal ataupun orientasi seksual (Darwin, 1999). Laki-laki tidak dilahirkan begitu saja dengan sifat maskulinnya secara alami, maskulinitas dibentuk oleh kebudayaan. Menurut Barker, hal yang menentukan sifat perempuan dan lakilaki adalah kebudayaan (Sya'ran, 2007).

Agresif merupakan salah satu sifat yang menunjukan maskulinitas seorang lakilaki. Agresivitas didefinisikan sebagai: a) kecenderungan habitual (yang dibiasakan) untuk memamerkan permusuhan; $b$ ) pernyataan diri secara tegas, penonjolan diri, penuntutan atau paksaan diri, pengejaran dengan penuh semangat suatu cita-cita dan, c) dominasi sosial, kekuasaan sosial, khususnya yang diterapkan secara ekstrim (Chaplin, 2002). Tomada \& Schneider pada tahun 1997 melakukan penelitian mendasarkan pada pilihan nominasi dari teman-teman sebaya dan guru. Hasilnya menunjukan anak laki-laki memperoleh skor yang lebih tinggi pada overt aggression (agresi fisik maupun verbal yang secara langsung dialami oleh korban) maupun relational aggression (agresi terselubung; bergosip, menolak berteman, dan mengeluarkan anggota kelompok) (Dayakisni \& Yuniarsi, 2008).

Senada dengan penelitian Tomada \& Schneider, pada penelitian Imaniar Aidul tahun 2011 dalam penelitiannya menggunakan subjek siswa kelas X SMA Muhammadiyah 15 Jakarta Barat, menunjukan bahwa lakilaki dinilai lebih sering melakukan agresif fisik dan agresif verbal, sementara perempuan lebih dinominasikan untuk secara langsung melakukan agresi relasi (agresi terselubung, misalnya menyebarkan gosip atau rumor tentang anak lain yang menjadi sasaran supaya teman-temannya menolak atau membencinya, mengeluarkan anak dari kelompoknya (Aidul, 2011).

Studi pendahuluan yang dilakukan peneliti pada 30 remaja laki-laki siswa SMA Negeri 67 Jakarta, terlihat bahwa rata-rata siswa laki-laki memiliki kecenderungan melakukan agresi verbal seperti menghina, mengumpat kata-kata kasar kepada sesama teman menjadi hal biasa diantara mereka. Terlihat sesekali mendorong dan memukul teman juga dilakukan oleh beberapa siswa laki-laki. Hal ini menunjukan bahwa siswa laki-laki memiliki kecenderungan melakukan agresivitas pada sesama laki-laki teman sebayanya.

Peristiwa- peristiwa yang berkaitan dengan agresivitas remaja yang dimuat di media massa, baik media cetak maupun elektronik antara lain berita mengenai tawuran pelajar. Tawuran pelajar beberapa waktu terakhir kembali mengemuka seolah menampar wajah banyak pihak. Sepanjang Januari hingga Juli 2015 terjadi kasus tawuran di wilayah Provinsi DKI Jakarta mencapai 63 kejadian. Dari jumlah tersebut, kasus tawuran tertinggi ada di Jakarta Timur yang mencapai 26 kasus. Berdasarkan data milik Polda Metro Jaya, sebanyak 26 kasus tawuran terjadi di Jakarta Timur, 8 kasus di Jakarta Pusat, 13 kasus di Jakarta Selatan, 2 kasus di Jakarta Utara, dan 8 kasus di Jakarta Barat (Kasus Tawuran Tertinggi Terjadi di Jakarta Timur, 2015)

Remaja cenderung memiliki sifat agresi. Secara psikologis, siswa - siswa sekolah menengah tingkat atas sedang mengalami masa remaja. Masa remaja adalah suatu tahap kehidupan yang bersifat peralihan dan tidak mantap. Selain itu masa remaja merupakan 
masa yang rawan oleh pengaruh- pengaruh negatif seperti narkoba, kriminal, dan kejahatan seks.

Secara tradisional masa remaja dianggap sebagai periode " badai dan tekanan", suatu masa dimana ketegangan emosi meninggi sebagai akibat dari perubahan fisik dan kelenjar (Hurlock, 1980). Berdasarkan beberapa penjelasan yang dikemukakan di atas, terlihat bahwa agresivitas identik dengan laki-laki. Agresivitas remaja laki-laki menjadi penting untuk diteliti karena dengan mengetahui gambaran hasil mengenai sejauh mana tingkat agresivitas yang dimiliki remaja laki-laki tersebut, dapat dijadikan acuan guru BK di sekolah untuk menangani siswa yang telah memiliki tingkat agresivitas tinggi sehingga diharapkan tingkat agresivitas dalam diri siswa dapat dihilangkan.

\section{ACUAN TEORITIK}

\section{Definisi Maskulinitas}

Maskulin merupakan sebuah bentuk konstruksi kelelakian terhadap gender yang mencakup berbagai aspek karateristik individu seperti, karakter atau kepribadian, perilaku peranan, okupasi, penampilan fisik, ekspresi verbal maupun non verbal ataupun orientasi seksual (Darwin, 1999).

\section{Karateristik Maskulinitas}

Brannon mengidentifikasi 4 komponen maskulin tradisional (Kimmel \& Aronson, 2003), yaitu sebagai berikut:

1. No Sissy Stuff: Seorang laki-laki sejati harus menghindari perilaku atau karakteristik yang berasosiasi dengan perempuan.

2. Be a Big Wheel: Maskulinitas dapat diukur dari kesuksesan, kekuasaan, dan pengaguman dari orang lain. Seseorang harus mempunyai kekayaan, ketenaran, dan status yang sangat lelaki. Atau dalam masyarakat Jawa: seorang laki-laki dikatakan sukses jika berhasil memiliki garwo (istri), bondo (harta), turonggo (kendaraan), kukiro (burung peliharaan), dan pusoko (senjata atau kesaktian).

3. Be a Sturdy Oak: Kelelakian membutuhkan rasionalitas, kekuatan, dan kemandirian. Seorang laki-laki harus tetap bertindak kalem dalam berbagai situasi, tidak menunjukkan emosi, dan tidak memunjukkan kelemahannya.

4. Give 'Em Hell: Laki-laki harus mempunyai aura keberanian dan agresif, serta harus mampu mengambil risiko walaupun alasan dan rasa takut menginginkan sebaliknya.

\section{Definisi Agresivitas}

Perilaku agresif adalah luapan emosi atas reaksi terhadap kegagalan individu yang ditujukan dalam bentuk perusakan terhadap orang atau benda dengan unsure kesengajaan yang diekspresikan dengan kata-kata (verbal) dan perilaku nonverbal (Schneider, 1964). Dollard \& Miller menjelaskan bahwa agresi merupakan hasil dari frustari karena terhalangnya suatu tujuan, bukan karena insting mati (Hidayat, 2011)

\section{Tujuan Agresivitas}

Berkowitz menyebutkan beberapa tujuan agresi selain melukai (non-injurious goal) (Abdul, 2014):

1. Coercion: Agresi boleh jadi hanyalah perilaku kasar yang tujuannya bukan untuk melukai. Menurut Patterson \&Tedeschi, tujuan utama coercion untuk mengubah perilaku orang lain atau menghentikan perilaku orang lain yang tidak sesuai dengan apa yang diharapkan(Berkowitz, 1993).

2. Power and Dominance: Perilaku agresi kadang ditujukan untuk meningkatkan dan menunjukan kekuasaan dan dominasi. Bagi orang yang menganggap penting dan ingin memelihara kekuasaan dan dominasinya kekerasan kadang menjadi salah satu cara untuk menunjukannya.

3. Impression Management: Perilaku agresi kadang ditunjukan dalam rangka menciptakan kesan. Orang yang konsep dirinya 
sebagai orang kuat ataupun berani seringkali menggunakan agresi untuk memperteguh kesan yang ingin diciptakannya.

\section{Faktor-Faktor Penyebab Munculnya Perilaku Agresif}

Menurut Sarwono dan Meinarno, menjelaskan penyebab timbulnya agresi pada individu (Sarwono \& Meinarno, 2009), antara lain:

1. Faktor Sosial

Frustrasi, terhambatnya atau tercegahnya upaya mencapai tujuan kerap menjadi penyebab agresi. Menurut Bushman, dkk kondisi ini menjadi mungkin dengan pemikiran bahwa agresi yang dilakukan individu tadi dapat mengurangi marah yang ia alami.

Agresi tidak selalu muncul karena frustrasi. Hukuman verbal atau fisik juga menjadi salah satu penyebab agresi. Contohnya kasus pemukulan 7 siswa terhadap kepala sekolah yang terjadi di SMK Muhammadiyah 1 Kabupaten Bantul, Yogyakarta. Pemukulan ini terjadi karena kekecewaan salah seorang siswa yang tidak naik kelas sehiingga siswa tersebut menjadi frustrasi (Kompas, 2008). Menyepelekan dan merendahkan sebagai ekspresi sikap arogan atau sombong, predictor yang kuat bagi munculnya agresi.

\section{Faktor Personal}

Faktor personal ini meliputi:

a. Pola tingkah laku berdasarkan kepribadian. Individu dengan pola tingkah laku A cenderung lebih agresif daripada individu dengan pola tingkah laku B. Menurut Fieldman, Tipe A identik dengan karakter terburu-buru, kompetitif, tingkah laku yang ditunjukkan oleh individu tipe B adalah bersikap sabar, kooperatif, nonkompetisi, dan non agresif (Feldman, Papalia, \& Old, 2008). b. Narsisme dan ancaman ego juga menjadi salah satu penyebab timbulnya agresi, dimana ini telah diteliti oleh (Gusman dan Baumeter, 1988) . Hasilnya individu yang narsis memiliki tingkat agresivitas lebih tinggi. Hal ini dikarenakan dirinya merasa terancam jika ada individu lain yang mempertanyakan dirinya. Mereka bereaksi dengan tingkat agresi yang tinggi terhadap umpan balik dari orang lain yang mengancam ego mereka yang besar. Maka, kemudian yang terwujud adalah tingkah laku agresif.

c. Perbedaan jenis kelamin, sering di ungkapkan bahwa laki-laki lebih agresif dari pada perempuan.

\section{Kebudayaan}

Penyebab timbulnya agresi adalah faktor kebudayaan. Lingkungan geografis, seperti pesisir atau pantai menunjukan karakter lebih keras daripada masyarakat yang hidup di pedalaman. Nilai dan norma yang mendasari sikap dan tingkah laku di masyarakat juga berpengaruh terhadap agresivitas satu kelompok.

4. Situasional

Penelitian terkait dengan cuaca dan tingkah laku menyebutkan bahwa ketidaknyamanan akibat panas menyebabkan kerusuhan dan bentukbentuk agresi lainnya. Hal yang paling sering muncul ketika udara panas adalah timbulnya rasa tidak nyaman yang berujung pada meningkatnya agresi sosial.

5. Sumberdaya

Daya dukung alam terhadap kebutuhan individu tak selamanya mencukupi. Oleh karena itu, dibutuhkan upaya lebih untuk memenuhi kebutuhan tersebut. Diawali dengan tawar-menawar, jika tidak mencapai kata sepakat, maka akan terbuka dua kemungkinan besar, pertama 
mencari sumber pemenuhan kebutuhan lain, kedua mengambil paksa dari pihak yang memilikinya.

\section{Media Massa}

Tayangan dari televisi berpotesi besar diimitasi oleh penontonnya. Beberapa penelitian tentang televisi dan kekerasan lebih banyak dilakukan baik di dalam negeri maupun diluar negeri secara teoritis penjelasan dari kajian ini mengarah pada teori belajar sosial.

\section{Bentuk-bentuk Perilaku Agresif}

Buss \& Perry merumuskan agresivitas menjadi empat bentuk(Buss \& Perry, 1992), sebagai berikut:

1. Physical Aggression (Agresif Fisik), perilaku agresi yang dapat diobservasi (terlihat/overt), Physical Aggression adalah kecenderungan individu untuk melakukan serangan secara fisik untuk mengekspresikan kemarahan atau agresi. Bentuk serangan fisik tersebut dapat berupa memukul, mendorong, menendang, mencubit dan lain sebagainya.

2. Verbal Aggression (Agresif Verbal), perilaku agresi yang dapat diobservasi (terlihat/overt). Verbal Aggression adalah kecenderungan untuk menyerang orang lain yang dapat merugikan dan menyakitkan kepada individu lain secara verbal, yaitu melalui kata-kata atau penolakan. Bentuk serangan verbal seperti cacian, ancaman, mengumpat, atau penolakan.

3. Anger (Kemarahan), beberapa bentuk anger adalah perasaan marah, kesal dan bagaimana cara mengontrol hal tersebut. Termasuk didalamnya irrtability (sifat lekas marah), yaitu mengenai tempramental, kecenderungan untuk cepat marah, dan kesulitan untuk mengendalikan amarah.

4. Hostility (Permusuhan), merupakan perilaku agresi yang covert (tidak terlihat). Hostility terdiri dari dua bagian, yaitu resentment (kemarahan,dendam, kebencian, kesebalan) seperti cemburu dan iri terhadap orang lain, dan suspicion seperti ketidakpercayaan, kekhawatiran, dan proyeksi dari rasa permusuhan orang lain.

\section{Definisi Remaja laki-laki Sekolah Menengah Atas}

Remaja didefinisikan sebagai suatu periode perkembangan dari transisi antara masa anak-anak dan dewasa, yang diikuti oleh perubahan biologis, kognitif, dan sosioemosional (Santrock, 1998). Menurut Konopka, remaja laki-laki di SMA adalah mereka dengan usia rata-rata 15 - 18 tahun termasuk pada fase remaja madya (Yusuf, 2012)

\section{Faktor yang Mempengaruhi Perkembangan Remaja}

1. Lingkungan Keluarga

a. Keberfungsian Keluarga, keluarga memiliki peran yang sangat penting dalam upaya mengembangkan pribadi anak. Keluarga juga dipandang sebagai institusi yang dpat memenuhi kebutuhan insani (manusiawi). Fungsi dasar keluarga adalah memberikan rasa memiliki, rasa aman, kasih sayang dan mengembangkan hubungan yang baik di antara anggota keluarga.

b. Kelas Sosial dan Status Ekonomi, pengaruh status sosial ekonomi terhadap kepribadian remaja adalah orangtua dari status ekonomi rendah cenderung lebih menekankan kepatuhan kepada figur-figur yang mempunyai otoritas; kelas menengah dan atas cenderung menekankan kepada pengembangkan inisiatif, keingintahuan dan kreativitas anak (Sarwono, 2012). 
2. Lingkungan Sekolah

Hurlock mengemukakan bahwa sekolah merupakan faktor penentu bagi perkembangan kepribadian anak (siswa) baik dalam cara berpikir, bersikap maupun cara berprilaku (Yusuf, 2012).

Sekolah yang sehat, didefiniskan sebagai kemampuan sekolah untuk berkembang, atau berubah dalam cara-cara yang produktif. Miles membagi sekolah yang sehat menjadi tiga bidang (Yusuf, 2012), yaitu:

a. Task Accomplistment (Penyelesaian tugas), yang menyangkut:a) alasan yang jelas, dapat diterima, dapat dicapai dan tujuan yang tepat, b) relatif lancar dalam berkomunikasi, baik sevara horizontal maupun vertikal ,dan c) penyamaan kekuatan yang optimal, gaya yang mempengaruhi kolaborasi, dan didasarkan pada kompetensi dan pemecahan masalah.

b. Integrasi Internal, yang menyangkut: a) pemanfaatan sumber daya yang penuh, b) identitas sekolah yang cukup jelas dan menarik sehingga para personelnya merasa menyatu dengan skolah, dan c) para personel memiliki semangat kerja yang tinggi, merasa senang dan merasa memiliki sekolah.

c. Saling beradaptasi antar sekolah dengan lingkungan, yaitu menyangkut: a) inovatif, kecenderungan untuk berkembang dan berubah setiap saat, b) otonomi, kemampuan untuk berbuat, bertindak berdasarkan kekuatan sendiri, c) adaptasi, baik disekolah dan lingkungan yang terjadi secara berkesinambungan, selama terjadinya kontak antara sekolah dengan lingkungan tersebut, dan d) ketepatan memecahkan masalah, kemampuan sekolah untuk mendetesi masalah yang munculnya tak dapat dielakkan.

3. Kelompok Teman Sebaya
Aspek kepribadian remaja yang berkembang dalam pengalamannya bergaul dengan teman sebaya, adalah:

a. Social cognition: kemampuan untuk memikirkan tentang pikiran, perasaan, motif dan tingkah laku dirinya dan orang lain. Kemampuan ini berpengaruh terhadap minatnya untuk bergaul atau membentuk persahabat degan teman sebayanya (Sigelman \& Shaffer, 1995).

b. Konformitas (conformity): terjadi apabila individu mengadopsi sikap atau perilaku orang lain karena merasa didesak oleh orang lain (baik desakan nyata atau hanya bayangan saja) (Santrock J. W., 2007). Desakan untuk conforms pada teman-teman sebaya cenderung sangat kuat selama masa remaja.

Keinginan remaja untuk di terima ditengah-tengah kelompoknya dan tidak dikeluarkan oleh kelompoknya ditentukan oleh tingkat kekuatan tekanan yang diberikan kelompok pada remaja, untuk mencapai tujuan tersebut maka remaja akan berusaha untuk konformitis dalam segala hal agar dapat diterima ditengah-tengah kelompok (Hurlock, 1999).

Keterkaitan antara konformitas dengan perilaku agresif pada remaja, secara khusus kelompok teman sebaya berperan penting bagi dalam timbulnya sikap agresif. Dilihat juga dari beberapa kasus tawuran yang terjadi hal tersebut akibat dari ajakan teman-teman sebayanya.

\section{Tugas Perkembangan Remaja}

Havighurst mengemukakan bahwa setiap individu pada setiap tahapan usia mempunyai tujuan untuk mencapai suatu kepandaian, keterampilan, pengetahuan, sikap dan fungsi tertentu, sesuai dengan kebutuhan pribadi yang timbul dari dalam dirinya sendiri dan tuntutan yang datang dari masyarakat di sekitanya (Sarwono, 2012).

Secara rinci, Havighurst (Sarwono, 
2012) menjelaskan tugas perkembangan itu:

1. Menerima kondisi fisik dan menggunakannya secara efektif

2. Menerima hubungan yang lebih matang dengan teman sebaya dari jenis kelamin mana pun.

3. Menerima peran jenis kelamin masingmasing

4. Berusaha melepaskan diri dari ketergantungan emosi terhadap orangtua dan orang dewasa lainnya.

5. Mempersiapkan karier ekonomi

6. Mempersiapkan perkawinan dan kehidupan berkeluarga

7. Merencanakan tingkah laku sosial yang bertanggung jawab

8. Mencapai sistem nilai dan etika tertentu sebagai pedoman tingkah lakunya.

Dengan kata lain remaja dituntut untuk belajar hal baru dalam memasuki tahap dewasa. Tuntutan ini biasanya menimbulkan kebingungan bagi remaja. Hal ini dikarenakan tugas perkembangan diatas juga ditentukan oleh tiga faktor lain yaitu kematangan fisik, desakan dari masyarakat dan motivasi dalam diri (Jensen, 1985)

\section{METODE PENELITIAN}

Penelitian ini bertujuan untuk mengetahui gambaran mengenai agresivitas pada remaja laki-laki di SMA Negeri DKI Jakarta. Metode yang digunakan dalam penelitian ini adalah metode survey yang bersifat deskriptif. Penelitian deskriptif adalah penelitian yang bertujuan untuk menerangkan suatu fenomena yang sedang terjadi (Rahmat \& Badrujaman, 2007). Misalnya pada penelitian ini akan tingkat agresivitas remaja laki-laki SMA melalui penelitian deskriptif.

Pada penelitian ini, yang menjadi populasi adalah remaja laki-laki siswa SMA Negeri di DKI Jakarta. Teknik pengambilan sampel yang digunakan adalah Gugus Bertahap Ganda (dua atau lebih) Multistages Random Sampling. Sehingga, dengan teknik pengambilan sampling ini diperoleh total sampel penelitian 523 siswa sebagai responden yang mewakili DKI Jakarta.

Penelitian ini menggunakan kuesioner yang dikembangkan oleh Buss\&Perry (1992) tentang agresivitas yang kemudian di adaptasi oleh peneliti dengan perubahan seperlunya berdasarkan kebutuhan penelitian.

\section{HASIL PENELITIAN}

Berdasarkan penyebaran insturmen the Aggression Questionare yang berisi 29 butir pernyataan dari total 523 responden, diperoleh hasil sebanyak 55 responden $(10.5 \%)$ memiliki agresivitas rendah, 448 responden (85.7\%) memiliki tingkat agresivitas pada kategori sedang dan 20 responden (3.8\%) memiliki tingkat agresivitas yang tinggi. Dapat disimpulkan bahwa mayoritas remaja lakilaki siswa SMA Negeri DKI Jakarta memiliki tingkat agresivitas sedang cenderung tinggi. Hasil secara rinci disajikan pada Tabel 1 berikut:

\begin{tabular}{cccc}
$\begin{array}{ccc}\text { Rentang } \\
\text { Skor }\end{array}$ & Kategori & $\mathrm{F}$ & $\mathrm{P}$ \\
$\mathrm{X}<68$ & Rendah & 55 & $10,5 \%$ \\
$68 \leq \mathrm{x}<106$ & Sedang & 448 & $85,7 \%$ \\
$106 \leq \mathrm{x}$ & Tinggi & 20 & $3,8 \%$ \\
\multicolumn{2}{c}{ Jumlah } & 523 & $100 \%$ \\
\hline
\end{tabular}

Tabel 1 Kategorisasi Hasil Penelitian

1. Gambaran Agresivitas Remaja LakiLaki ditinjau dari Jenjang Kelas.

Secara keseluruhan, gambaran agresivitas remaja laki-laki siswa SMA Negeri DKI Jakarta dapat dijabarkan berdasar data per-jenjang kelas seperti dalam Tabel 2 berikut:

\begin{tabular}{cccccc}
\hline \multirow{2}{*}{ Kelas } & \multicolumn{4}{c}{ Kategorisasi } & Jumlah \\
& & Tinggi & Sedang & Rendah & \\
\hline \multirow{2}{*}{$\mathrm{X}$} & $\mathrm{F}$ & 12 & $201 \%$ & 27 & 240 \\
& $\mathrm{P}$ & $5 \%$ & 83,75 & $11,25 \%$ & $100 \%$
\end{tabular}




\begin{tabular}{cccccc}
\hline XI & F & 7 & 216 & 23 & 246 \\
& P & $2,8 \%$ & $87,8 \%$ & $9,4 \%$ & $100 \%$ \\
XII & F & 1 & 31 & 5 & 37 \\
& P & $2,7 \%$ & $83,8 \%$ & $13,5 \%$ & $100 \%$ \\
\hline
\end{tabular}

Tabel 2 Gambaran Agresivitas Remaja Laki-laki Siswa SMA Negeri DKI Jakarta Perjenjang Kelas

Dapat disimpulkan bahwa baik kelas X, XI dan XII memilki persentase tingkat agresivitas dengan kategori sedang. Artinya, remaja laki-laki siswa SMA Negeri di DKI Jakarta memiliki tingkat agresivitas dengan kategori sedang. Perbandingan persentase berdasarkan jenjang kelas dapat divisualisasikan dalam Grafik 1:

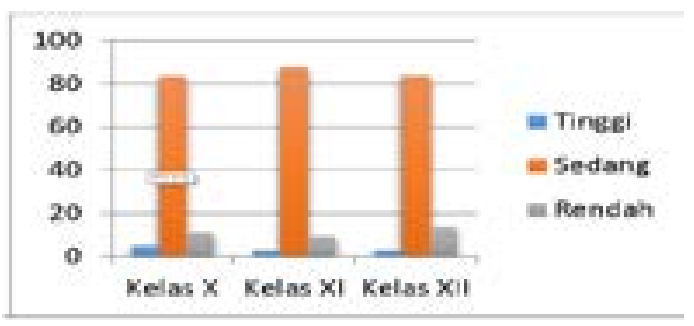

Gambar 1 Perbandingan Persentase Berdasarkan Jenjang Kelas

2. Gambaran agresivitas Remaja Laki-laki ditinjau dari wilayah.

Secara Keseluruhan, gambaran agresivitas remaja laki-laki siswa SMA Negeri DKI Jakarta dapat dijabarkan per sekolah seperti dalam Tabel 3 berikut:

\begin{tabular}{cccccc}
\hline \multirow{2}{*}{ Wilayah DKI } & \multicolumn{3}{c}{ Kategorisasi } \\
Jak-Bar & $\mathrm{F}$ & 7 & 97 & 6 & 110 \\
& $\mathrm{P}$ & $6,4 \%$ & $88,2 \%$ & $5,4 \%$ & $100 \%$ \\
Jak-Pus & $\mathrm{F}$ & 6 & 74 & 7 & 87 \\
& $\mathrm{P}$ & $6,9 \%$ & $85,1 \%$ & $8 \%$ & $100 \%$ \\
Jak-Tim & $\mathrm{F}$ & 2 & 100 & 18 & 120 \\
& $\mathrm{P}$ & $1,7 \%$ & $83,3 \%$ & $15 \%$ & $100 \%$ \\
Jak-Sel & $\mathrm{F}$ & 2 & 82 & 11 & 95 \\
& $\mathrm{P}$ & $21 \%$ & $86,3 \%$ & $11,6 \%$ & $100 \%$ \\
Jak-Ut & $\mathrm{F}$ & 3 & 95 & 13 & 111 \\
& $\mathrm{P}$ & $2,7 \%$ & $85,6 \%$ & $11,7 \%$ & $100 \%$ \\
\hline
\end{tabular}

Tabel 3 Gambaran Agresivitas Remaja Laki-laki Siswa SMA Negeri Per-Wilayah DKI Jakarta

Dari setiap wilayah kota di-DKI Jakarta menunjukan gambaran agresivitas yang sedang sebagai persentase paling tinggi. Sehingga dapat ditarik kesimpulan bahwa mayoritas remaja laki-laki siswa SMAN di DKI Jakarta memiliki agresivitas yang sedang. Dapat diketahui di wilayah Jakarta Pusat memiliki tingkat agresivitas yang tinggi di bandingkan dengan wilayah lainnya dengan persentase $6.9 \%$. Hal ini sesuai dengan pendapat yang dikemukakan Neta S Pane (Ketua Presidium Indonesia Police Watch (IPW)) sejumlah wilayah di DKI Jakarta masih rawat tindak kriminalitas, menurutnya Jakarta Pusat memiliki kriminalitas tinggi. Kemiskinan dan faktor lingkungan menjadi hal pemicu tindak kriminal (Alfian, 2016). Sejalan dengan pendapat Neta, berdasarkan data Pemprov DKI Jakarta mengenai kawasan rawan konflik Provinsi DKI Jakarta, menyebutkan bahwa pada wilayah Jakarta Pusat penyebab timbulnya konflik dikarenakan rumah tangga miskin dan tingkat kepadatan penduduk yang tinggi jika dibandingkan dengan luas wilayah Jakarta Pusat (Ratiyono, 2016). kemudian wilayah Jakarta Barat memiliki agresivitas yang sedang dengan persentase tertinggi yaitu $88.2 \%$, pada wilayah Jakarta Timur memiliki gambaran agresivitas yang rendah dengan persentase tertinggi sebesar 
$15 \%$.

3. Gambaran Agresivitas Remaja Laki-laki Berdasarkan Aspek

Aspek agresivitas remaja laki-laki siswa SMA Negeri di DKI Jakarta memiliki empat aspekyang aka diukuryaitu agresi fisik (physical aggression), agresi verbal (verbal aggression), kemarahan (anger), dan sikap permusuhan (hostility). Secara keseluruhan memiliki proporsi yang berbeda. Perbedaan terlihat dari jumlah butir dari setiap aspek yang berbeda sesuai dengan aspek masingmasing aspek sehingga secara keseluruhan pemetaan tingkat agresivitas remaja lakilaki perlu dilakukan per Aspek untuk memperoleh hasil yang menggambarkan gambaran agresivitas, seperti dalam tabel 4 berikut:

\begin{tabular}{|c|c|c|c|c|c|c|}
\hline \multirow{3}{*}{ Aspek } & \multicolumn{6}{|c|}{ Kategorisasi } \\
\hline & \multicolumn{2}{|c|}{ Tinggi } & \multicolumn{2}{|c|}{ Sedang } & \multicolumn{2}{|c|}{ Rendah } \\
\hline & $\mathrm{F}$ & $\mathrm{P}$ & $\mathrm{F}$ & $\mathrm{P}$ & $\mathrm{F}$ & $\mathrm{P}$ \\
\hline $\begin{array}{l}\text { Agresi } \\
\text { Fisik }\end{array}$ & 86 & $16,1 \%$ & 375 & $71 \%$ & 61 & $11,7 \%$ \\
\hline $\begin{array}{l}\text { Agresi } \\
\text { Verbal }\end{array}$ & 110 & $21 \%$ & 350 & $72 \%$ & 33 & $67 \%$ \\
\hline $\begin{array}{l}\text { Kemarah } \\
\text { an }\end{array}$ & 54 & $10,3 \%$ & 355 & $57,9 \%$ & 114 & $21 \%$ \\
\hline $\begin{array}{l}\text { Permusuh } \\
\text { an }\end{array}$ & 70 & $15 \%$ & 404 & $77,3 \%$ & 40 & $75 \%$ \\
\hline
\end{tabular}

Tabel 4 Gambaran Agresivitas Remaja Laki-laki Siswa SMA Negeri di DKI Jakarta PerAspek

Berdasarkan persentase di tiaptiap aspek agresivitas remaja laki-laki, maka dapat ditarik kesimpulan bahwa tiga dari empat aspek agresivitas memiliki kecenderungan tingkat agresivitas sedang hingga tinggi pada aspek agresi fisik, agresi verbal dan permusuhan dengan persentase pada agresi fisik yang sedang $71.9 \%$ dan agresi fisik terkategorisasi tinggi sebanyak $16.4 \%$. persentase pada agresi verbal kategori sedang sebanyak $72.7 \%$ dan agresi verbal dengan kategori tinggi sebanyak $21.8 \%$, kemudian pada aspek permusuhan tingkat agresivitas terkategori sedang sebanyak $77.3 \%$ yang menjadi persentase terbesar dari seluruh aspek agresivitas dan terkategori tinggi $15.1 \%$. Sedangkan pada aspek kemarahan tingkat agresivitas remaja laki-laki memiliki kecenderungan sedang hingga rendah dengan persentase $67.9 \%$ terkategorisasi sedang dan $21.8 \%$ terkategorisasi rendah. Adapun perbandingan persentase di tiap-tiap aspek divisualisasikan dalam grafik berikut:

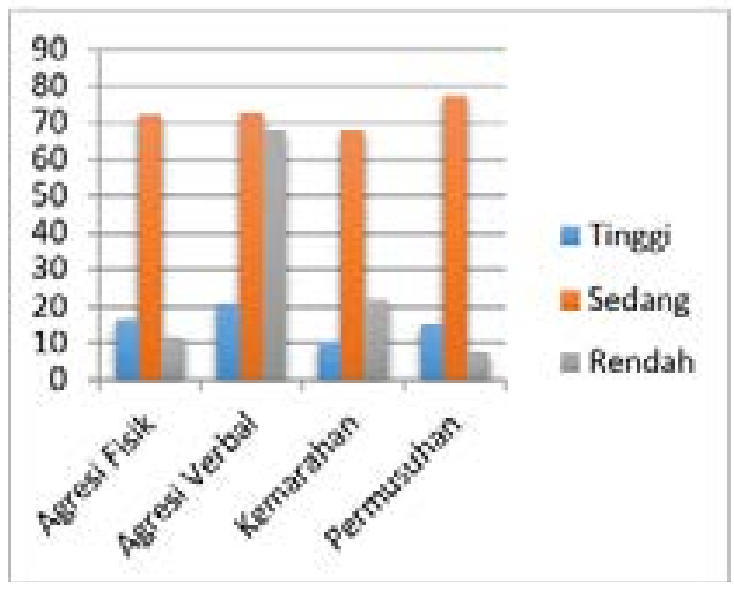

Grafik 2 Perbandingan Persentase Berdasarkan Aspek Agresivitas

\section{KESIMPULAN, IMPLIKASI, DAN SARAN}

\section{Kesimpulan}

Berdasarkan hasil penelitian gambaran agresvitas remaja laki-laki siswa SMA Negeri DKI Jakarta yang telah dipaparkan sebelumnya, dapat disimpulkan bahwa:

1. Berdasarkan hasil penelitian diatas gambaran agresivitas pada remaja laki-laki siswa SMA Negeri di DKI Jakarta terkategorisasi sedang dengan persentase sebesar $85.7 \%$.

2. Gambaran agresivitas pada remaja laki-laki siswa SMA Negeri di DKI Jakarta setiap aspek menunjukan hasil yang tinggi pada kategori sedang 
dengan persentase sebagai berikut pada aspek agresi fisik $71.9 \%$, aspek agresi verbal $72.7 \%$, pada aspek kemarahan memperoleh persentase sebesar $67.9 \%$ dan pada aspek permusuhan $77.3 \%$.

3. Aspek permusuhan menunjukan hasil yang tinggi pada kategori sedang dengan persentase $77.3 \%$ yang menjadikan aspek ini menjadi aspek dengan persentase tertinggi. Artinnya, remaja laki-laki menilai dirinya memiliki kecenderungan menyimpan dendam, kemarahan, kebencian, ketidakpercayaan, kekhawatiran, rasa permusuhan dengan orang lain.

4. Remaja laki-laki kelas XI memiliki tingkat agresivitas yang tinggi pada kategori sedang dengan persentase $87.8 \%$ lebih tinggi dibandingkan dengan kelas X dan kelas XII dari jumlah responden per-jenjang kelas.

5. Dari lima wilayah di DKI Jakarta yang memiliki tingkat agresivitas tinggi terdapat di wilayah Jakarta Pusat dengan persentase $6.9 \%$, kemudian wilayah Jakarta selatan memiliki agresivitas yang sedang dengan persentase tertinggi yaitu $86.3 \%$, pada wilayah Jakarta Timur memiliki gambaran agresivitas yang rendah dengan persentase tertinggi sebesar $15 \%$.

\section{Implikasi}

Berdasarkan hasil penelitian yang telah dilaksanakan, terdapat beberapa hal yang dapat dikaji dan dipelajari bersama mengenai agresivitas remaja laki-laki siswa SMA Negeri di DKI Jakarta. Tingkat agresivitas pada remaja laki-laki siswa SMA Negeri di DKI Jakarta yang memiliki kecenderungan tinggi ada pada aspek permusuhan yang kemudian diikuti dengan agresi verbal. Permusuhan merupakan kecenderungan menyimpan dendam, kemarahan, kebencian, ketidakpercayaan, kekhawatiran, rasa permusuhan dengan orang lain.
Siswa laki-lakikelas XI menjadi jenjang kelas dengan persentase agresivitas yang tinggi dibandingkan kelas X dan Kelas XII. Hal ini mungkin terjadi karena siswa kelas XI memiliki kecenderungan menunjukan keberadaan diri kepada orang lain memungkinkan remaja lakilaki melakukan tindakan agresi tersebut.

Pada lima wilayah DKI Jakarta, mayoritas tingkat agresivitas remaja perwilayah terkategorisasi sedang cenderung tinggi dengan persentase diatas $80 \%$. Di wilayah Jakarta Pusat memiliki persentase kategori tertinggi dengan $6.9 \%$ jika di bandingkan dengan wilayah di DKI Jakarta lainnya. Hal ini sesuai dengan pendapat yang dikemukakan Neta $\mathrm{S}$ Pane (Ketua Presidium Indonesia Police Watch (IPW)) sejumlah wilayah di DKI Jakarta masih rawat tindak kriminalitas, menurutnya Jakarta Pusat memiliki kriminalitas tinggi. Kemiskinan dan faktor lingkungan menjadi hal pemicu tindak kriminal (Alfian, 2016). Sejalan dengan pendapat Neta, berdasarkan data Pemprov DKI Jakarta mengenai kawasan rawan konflik Provinsi DKI Jakarta, menyebutkan bahwa pada wilayah Jakarta Pusat penyebab timbulnya konflik dikarenakan rumah tangga miskin dan tingkat kepadatan penduduk yang tinggi jika dibandingkan dengan luas wilayah Jakarta Pusat (Ratiyono, 2016).

\section{Saran}

1. Bagi Pihak Sekolah, penelitian ini dapat menjadi bahan referensi kepada sekolah untuk dilakukannya pengarahan mengenai kecerdasan emosional khususnya dalam melakukan pelatihan ESQ (Emotional Spiritual Quotient) kepada siswa yang memiliki tingkat agresivitas sedang hingga tinggi.

2. Bagi Guru Bimbingan dan Konseling di Sekolah, penelitian ini kemungkinan dapat menjadi referensi untuk memaksimalkan layanan responsif dalam bentuk; konseling individu dan konseling kelompok dengan pendekatan yang sesuai dengan agresivitas dan memberikan layanan 
dasar berupa bimbingan klasikal dan juga parenting workshop kepada orangtua siswa.

3. Bagi Orangtua, dapat menciptakan lingkungan keluarga yang saling mendukung, berdialog mengenai berbagai hal agar tumbuh kepercayaan pada diri anak untuk terbuka dan orangtua dapat memberi masukan agar anak tidak salah dalam mengambil keputusan.

4. Bagi Prgoram Studi Bimbingan dan Konseling, hasil penelitian ini dapat menjadi bahan untuk mengembangkan konten materi kuliah khususnya pada pemberian tugas berkaitan dengan agresivitas siswa agar sesuai dengan keadaan di Lapangan (Sekolah).

5. Mahasiswa Program Studi Bimbingan dan Konseling dapat menggunakan hasil penelitian ini sebagai alternatif referensi untuk dilakukannya penelitian selanjutnya berupa bimbingan maupun konseling pada siswa yang memiliki tingkat agresivitas yang tinggi.

\section{DAFTAR PUSTAKA}

Abdul, A. H. (2014). Psikologi Sosial: Integrasi Pengetahuan Wahyu dan Pengetahuan Empirik. Jakaarta: PT Rajagrafindo Persada.

Alfian, T. (2016, Januari 25). Jakarta Pusat Rawan Kejahatan. Dipetik Febuari 8, 2017, dari www.harnas.com: http://m.harnas. co/2016/01/25/jakarta-pusat-rawankejahatan

Berkowitz, R. A. (1993). Aggression: Its Causes, Consequences, and Control. USA: McGraw-Hill, Inc.

Buss, A. H., \& Perry, M. P. (1992). The Aggression Questionare. Journal of Personality and Psychology, 452 - 459.

Chaplin, J. P. (2002). Kamus Lengkap Psikologi. Jakarta: PT Raja Grafindo Persada.

Dayakisni, T., \& Yuniarsi, S. (2008). Psikologi Lintas Budaya. Malang: UMM Press.
Feldman, R. D., Papalia, D. E., \& Old, S. W. (2008). Human Development. Jakarta: Kencana.

Hidayat, D. R. (2011). Teori dan Aplikasi Psikologi Kepribadian Dalam Konseling. Bogor: Ghalia Indonesia.

Hurlock, E. B. (1980). Psikologi Perkembangan Suatu Pendekatan Rentang Kehidupan. Jakarta: Erlangga.

Hurlock, E. (1999). Psikologi Perkembangan: Suatu Pendekatan Sepanjang Ruang Kehidpan Ed. 5. Jakarta: Erlangga.

Jensen, J. C. (1985). Adolescence: Theories, Research, Applications. St. Paul, San Fransisco: West Publishing Co.

Kasus Tawuran Tertinggi Terjadi di Jakarta Timur. (2015, Juli 27). Dipetik November 4, 2016, dari www.beritasatu.com: http://www. beritasatu.com/megapolitan/294154kasus-tawuran-tertinggi-terjadi-dijakarta-timur.

Rahmat, D., \& Badrujaman, A. (2007). Diklat Kuliah Metodologi Penelitian. Jakarta: Jurusan BK FIP UNJ.

Ratiyono. (2016, Febuari). Dipetik Febuari 8, 2017, dari www.jakarta.go.id.

Santrock, J. W. (1998). Adolescence (7th edition). New Yorl: McGraw Hill.

Santrock, J. W. (2007). Psikologi Pendidikan Ed. 2. Jakarta: Prenada Media Grup.

Sarwono, S. W. (2012). Prikologi Remaja. Jakarta: Rajawali Pers.

Sarwono, S. W., \& Meinarno. (2009). Psikologi Sosial. Jakarta: Salemba Humanika.

Schneider, A. A. (1964). Personal Adjustment and Mental Health. New York: Holt, Rinchant \& Winston.

Sigelman, C. K., \& Shaffer, D. R. (1995). Life Span human Development. California: brooks/ Cole Publishing Company.

Sya'ran, N. (2007). Maskulinitas dalam Iklan Gudang Garam: Analisis Semiotik atas Iklan Gudang Garam. Yogyakarta. 
Yusuf, S. L. (2012). Perkembangan Peserta Didik. Jakarta: PT Raja Grafindo Persada.

\section{Instrumen Agresivitas Remaja}

Laki-laki

Tujuan Penelitian

M e m pe ro le h
informasi serta
data empiris
m e n g e $\mathrm{n} \mathrm{a} \mathrm{i}$
$\mathrm{g}$ a $\mathrm{m} \mathrm{b}$ a $\mathrm{r}$ a $\mathrm{n}$
agresivitas pada
remaja laki-laki di
SMA Negeri DKI
Jakarta

Dosen Pembimbing I: Dr. Susi Fitri S.Pd., M.Si.,Kons

Dosen Pembimbing II: Dra. Meithy Intan R.L., M. Pd
Nama Peneliti : Dewi Puspasari
Kontak
: 081315192757 / dewi.puspasari. kuliah@gmail. com

Instrumen ini merupakan alat ukur yang digunakan untuk mengetahui gambahwan agresivitas remaja laki-laki. Anda diminta untuk mengisi instrumen ini dengan sejujurnya sesuai dengan keadaan diri sendiri. Tidak ada jawaban yang benar atau salah, jawaban anda akan dijaga kerahasiaannya dan tidak akan mempengaruhi nilai anda dalam pelajaran sekolah. Mohon periksa kembali jawaban anda, sebelum dikumpulkan. Pastikan anda menjawab semua pernyataan. Atas perhatian dan kerjasamanya saya ucapkan terima kasih.

Identitas Diri

Nama : Kelas Usia Tahun

\section{Petunjuk Pengisian Instrumen}

Bacalah setiap butir pernyataan dengan teliti kemudian pilihlah salah satu dari 5 alternatif jawaban yang sesuai dengan diri anda dengan memberikan tanda cek list $(\sqrt{ })$ pada kolom yang di sediakan.

STS : Bila pernyataan tersebut sangat tidak sesuai dengan diri anda

TS : Bila pernyataan tersebut tidak sesuai dengan diri anda

$\mathrm{N} \quad$ : netral

S : Bila pernyataan tersebut sesuai dengan diri anda

SS : Bila pernyataan tersebut sangat sesuai dengan diri anda 


\begin{tabular}{|c|c|c|c|c|c|c|}
\hline No & Pernyataan & STS & TS & $\mathbf{N}$ & $\mathbf{S}$ & SS \\
\hline 1. & $\begin{array}{l}\text { Jika seseorang memukul saya, maka saya } \\
\text { akan membalasnya. }\end{array}$ & & & & & \\
\hline 2. & $\begin{array}{l}\text { Saya seseorang yang mudah marah tapi } \\
\text { mudah untuk reda (tidak marah lagi) }\end{array}$ & & & & & \\
\hline 3. & $\begin{array}{l}\text { Saat merasa kecewa, saya akan menunjuk- } \\
\text { kan kejengkalan saya. }\end{array}$ & & & & & \\
\hline 4. & $\begin{array}{l}\text { Terkadang, saya tidak bisa menahan keingi- } \\
\text { nan diri saya untuk menyerang orang lain. }\end{array}$ & & & & & \\
\hline 5. & $\begin{array}{l}\text { Saya merasa menjadi seseorang yang mu- } \\
\text { dah termakan oleh rasa cemburu }\end{array}$ & & & & & \\
\hline 6. & Saya sulit dalam mengendalikan emosi. & & & & & \\
\hline 7. & $\begin{array}{l}\text { Orang lain nampaknya mendapatkan kebe- } \\
\text { runtungan (bernasib baik). }\end{array}$ & & & & & \\
\hline 8. & $\begin{array}{l}\text { Beberapa teman saya menganggap saya } \\
\text { adalah orang yang pemarah }\end{array}$ & & & & & \\
\hline 9. & $\begin{array}{l}\text { Ada beberapa orang yang mendesak (me- } \\
\text { mancing emosi) saya terlalu parah sehing- } \\
\text { ga kami berkelahi. }\end{array}$ & & & & & \\
\hline 10. & $\begin{array}{l}\text { Saya akan memberitahukan kepada teman } \\
\text { saya secara terang-terangan ketika saya ti- } \\
\text { dak setuju dengan mereka }\end{array}$ & & & & & \\
\hline 11. & $\begin{array}{l}\text { Ketika saya rasa seseorang mengganggu } \\
\text { saya, saya akan katakan terus terang pada } \\
\text { mereka }\end{array}$ & & & & & \\
\hline 12. & $\begin{array}{l}\text { Ketika seseorang baik kepada saya, saya } \\
\text { menduga mereka ada maunya }\end{array}$ & & & & & \\
\hline 13. & $\begin{array}{l}\text { Saya sering terlibat dalam pertengkaran } \\
\text { lebih dari orang-orang pada umumnya. }\end{array}$ & & & & & \\
\hline 14. & $\begin{array}{l}\text { Saya sering kali merasa tidak sependapat } \\
\text { dengan orang lain. }\end{array}$ & & & & & \\
\hline 15. & Saya orang yang mudah marah & & & & & \\
\hline 16. & $\begin{array}{l}\text { Saya mengetahui bahwa beberapa "teman" } \\
\text { membicarakan saya dibelakang saya. }\end{array}$ & & & & & \\
\hline 17. & $\begin{array}{l}\text { Terkadang saya merasa orang-orang men- } \\
\text { ertawakan saya dibelakang saya. }\end{array}$ & & & & & \\
\hline 18. & $\begin{array}{l}\text { Terkadang saya merasa saya telah mem- } \\
\text { perlakukan seseorang dengan tidak adil da- } \\
\text { lam hidup. }\end{array}$ & & & & & \\
\hline 19. & $\begin{array}{l}\text { Saya akan memukul orang lain jika cend- } \\
\text { erung menghasut. }\end{array}$ & & & & & \\
\hline 20. & $\begin{array}{l}\text { Saya pernah mengancam orang yang saya } \\
\text { kenal }\end{array}$ & & & & & \\
\hline
\end{tabular}




\begin{tabular}{|c|c|c|c|c|c|c|}
\hline No & Pernyataan & STS & TS & $\mathbf{N}$ & $\mathrm{S}$ & SS \\
\hline 21. & $\begin{array}{l}\text { Saya akan terlibat dalam perdebatan keti- } \\
\text { ka orang-orang tidak sependapat dengan } \\
\text { saya. }\end{array}$ & & & & & \\
\hline 22. & $\begin{array}{l}\text { Terkadang saya merasa seperti bom yang } \\
\text { siap diledakkan. }\end{array}$ & & & & & \\
\hline 23. & $\begin{array}{l}\text { Terkadang saya hilang kesabaran tanpa } \\
\text { alasan yang jelas. }\end{array}$ & & & & & \\
\hline 24. & $\begin{array}{l}\text { Teman-teman berkata bahwa saya orang } \\
\text { yang agak membangkang. }\end{array}$ & & & & & \\
\hline 25. & $\begin{array}{l}\text { Saya akan merusak sesuatu, jika saya san- } \\
\text { gat marah }\end{array}$ & & & & & \\
\hline 26. & $\begin{array}{l}\text { Jika saya terpaksa harus menggunakan ke- } \\
\text { kerasan untuk melindungi hak saya, maka } \\
\text { saya akan melakukannya. }\end{array}$ & & & & & \\
\hline 27. & $\begin{array}{l}\text { Saya bertanya-tanya penyebab dari } \\
\text { perasaan sedih yang saya rasakan }\end{array}$ & & & & & \\
\hline 28. & $\begin{array}{l}\text { Saya pikir tidak ada alasan yang baik dalam } \\
\text { memukul seseorang. }\end{array}$ & & & & & \\
\hline 29. & $\begin{array}{l}\text { Saya curiga pada orang asing yang terlalu } \\
\text { ramah }\end{array}$ & & & & & \\
\hline
\end{tabular}

\section{Terima Kasih $\odot$}

Jika ada pertanyaan dan hal lain berkaitan dengan instrumen / penelitian ini dapat menghubungi saya pada kontak diatas. 